ECOLOGICA, Vol. 28, No 101 (2021), 16-21

https://doi.org/10.18485/ecologica.2021.28.101.4

Originalni naučni rad

UDC: $502.14(4-672 E U)$

\title{
Ekološka politika Evropske unije
}

\section{Ecological Policy of the European Union}

\author{
Jovana Dinić ${ }^{1}$, Jovan Bukovala², Nikolaj Ivannikov ${ }^{3}$ \\ 1 Univerzitet u Beogradu, Fakultet političkih nauka, Beograd, Jove Ilića 165; \\ University of Belgrade, Faculty of Political Sciences, Belgrade, Jove Ilića 165. \\ ¿Univerzitet u Beogradu, Filozofski fakultet, Beograd, Čika-Ljubina 18-20; \\ University of Belgrade, Faculty of Philosophy, Belgrade, Čika-Ljubina 18-20. \\ 3Univerzitet "Union - Nikola Tesla", Fakultet za poslovne studije i pravo, Beograd, Jurija Gagarina 149a; \\ University "Union - Nikola Tesla", Faculty of Business Studies and Law, Belgrade, Jurija Gagarina 149a.
}

Rad primljen: 24.01.2021, Rad prihvaćen: 25.02.2021.

Sažetak: Procesi globalizacije doveli su do ubrzanog naučnog i tehnološkog razvoja i novih bezbednosnih asimetričnih izazova. Zbog upotrebe novih izvora energije, porasta stanovništva, upotrebe različitih vrsta nekonvencionalnog oružja i nedostatka ekološke svesti, ljudski život i životna sredina su ugroženi. Zaštita životne sredine postala je jedan od najvažnijih nacionalnih interesa svih zemalja sveta. Zaštita životne sredine na područjima na kojima se sprovodi važno je mjesto u aktivnostima Evropske unije, gde je normativno i institucionalno uređena. Politika zaštite životne sredine Evropske unije suočena je s brojnim izazovima, a to su preventivne mere zaštite, a prilagođavanje ekološke svijesti vrlo je važno.

Ključne reči: Evropska unija, politika zaštite životne sredine, zaštita životne sredine, ekologija, klimatske promjene, evropski identitet.

\begin{abstract}
The processes of globalization have led to accelerated scientific and technological development and new security asymmetric challenges. Due to the use of new energy sources, population growth, the use of various types of unconventional weapons and the lack of environmental awareness, human life and the environment are innate. Environmental protection has become one of the most important national interests of all countries in the world. Environmental protection in the areas where it is taken is an important place in the activities of the European Union, where it is normatively and institutionally regulated. The environmental policy of the European Union is facing with numerous challenges, which are preventive protection measures and adjustment of environmental awareness is very important.
\end{abstract}

Keywords: European Union, environmental policy, environmental protection, ecology, climate changes, European identity.

\footnotetext{
1orcid.org/0000-0002-0923-1281, e-mail: jokadimitrijevic93@gmail.com

2orcid.org/0000-0002-1088-9638, e-mail: jovan.bukovala@f.bg.ac.rs

${ }^{3}$ orcid.org/0000-0002-3913-0190, e-mail: nikolaj.ivannikov@fpsp.edu.rs
} 


\section{UVOD / INTRODUCTION}

Razvoj nauke i tehnologije doveo je do pozitivnih i negativnih promena za čovečanstvo. Osim novih tehnoloških inovacija i dostignuća, bržeg i efikasnijeg transporta i komunikacije, tehnoloških razvoj je uzokovao i nove bezbednosne pretnje. Nove asimetrične bezbednosne pretnje je teško predvideti i sprečiti, što dodatno otežava nacionalne i međunarodne preventivne zaštitne akcije. Jedna od najopasnijih bezbednosnih pretnji današnjice je ugrožavanje životne sredine. Ugrožavanje životne sredine kroz zagađivanje vazduha, vode, zemljišta može izazvati zdravstvene probleme ljudi sa smrtnim ishodom i ekonomske gubitke.

U globalizacijskim turbulencijama devedesetih godina dvadesetog veka, Evropska unija je postala vodeća svetska organizacija koja teži zaštiti životne sredine. Definisanjem normativno-pravnog i institucionalnog okvira u oblasti zaštite ozonskog omotača, biotehnologija i biodiverziteta dovelo ju je do liderske pozicije u zaštiti životne sredine. Evorpska komisija i Evropski parlament imali su ključan uticaj da Evropska unija preuzme vodeću ulogu u svetu u ekološkoj politici i usvajanju strogih normativnih standarda. Osim normativno-pravnog i institucionalnog okvira u vezi sa ekološkom politikom Evropske unije na nadnacionalnom nivou, važan uticaj su imali i propisi o zaštiti životne sredine usvojenih na nacionalnom nivou. Zbog ugrožavanja nacionalne ekološke politike država članica i dinamičnih političkih kretanja Evropske unije, došlo je do ekološkog osvešćivanja i insistiranja država članica za strožiju politiku zaštite životne sredine. Politika proširenja evropske unije i pitanje evropskog identitea su dodatno otežale jedinstvo država članica u donošenju i implementaciji odluka u vezi sa ekološkom politikom.

\section{MATERIJALI I METODE / MATERIALS AND METHODS}

$U$ istraživanju su korišćene analitičko deduktivna $\mathrm{i}$ induktivna metoda. Induktivna metoda se koristi da se uz pomoć pojedinačnih činjenica dođe do opšteg zaključka, a deduktivna obrnuto, da se iz opšteg zaključka dođe do pojedinačne činjenice. Glavna metoda $u$ istraživanju je metoda analize sadržaja dokumenata.

Metoda analize sadržaja (dokumenata) je operativna metoda, prisutna u fazi prikupljanja podataka i upotrebava se u razmatranju proverenog naučnog saznanja, neverifikovanog naučnog saznanja, empirijskog saznanja, kao i nepostojećeg saznanja o predmetu istraživanja, tako da se vrši rekonstrukcija postojećih značenja i otkrivaju se nova saznanja. Analiza sadržaja dokumenata se koristi u kvalitativnim, ali i u kvantitativnim istraživanjima, zato što je metoda koja sadrži i kvalitativne i kvantitativne elemente (Krippendorf, 2009). Analizom sadražaja dokumenata političke prirode (izveštaji, direktive, statuti, medijske izjave) moguće je prepoznati $i$ odvojiti istinite od manje istinitih $i$ utvrditi potpuni izostanak informacije ili beleške o nekom događaju.

\section{REZULTATI I DISKUSIJA / RESULTS AND DISCUSSION}

Analizom značajnih strateških dokumenata i relevantne naučne literature u vezi sa ovom tematikom utvrđeno je da su se u poslednjoj deceniji područja delovanja Evropske unije udaljila od prvobitne misije Evropske ekonomske zajednice - da uspostavi zonu slobodne trgovine i fokusira se na ekonomiju. Sada su područja delovanja Unije izmenjena i šira: digitalizacija Evrope, evropski zeleni posao, ekonomija u interesu običnih ljudi, promovisanje evropskog načina života $i$ jačanje međunarodnog ugleda EU (Nova strateška agenda za Evropsku uniju 2019-2024. godine). Bez obzira na izmenjene prioritete delovanja EU, očuvanje životne sredine od različitih bezbednosnih pretnji, zaštita čovekovog zdravlja i racionalna upotreba prirodnih resursa ostaju ključni cilj ekološke politike EU.

Da bi se razmatrali novi izazovi ekološke politike EU, treba uzeti u obzir normativno-pravni i institucionalni okvir ekološke politike koji su Uniju učinili liderom među organizacijama u bavljenju zaštitom životne sredine. Kada je reč o normativnopravnom okviru ekološke politike Evropske unije, treba istaći najvažnija dokumenta. Rimskim ugovorima iz 1958. godine nije definisana nadležnost Evropske Ekonomske zajednice za ekološku politiku, već je svaka država članica ovu oblast uredila na nacionalnom planu. Međutim, kako su ekološka pitanja postajala sve značajnija, nakon prve Konferencije Ujedinjenih nacija o čovekovoj životnoj sredini iz 1972. godine na samitu Evropske zajednice u Parizu od komisije je zatraženo da razradi akcioni program zaštite životne sredine (Volf-Nidermajer, 2004).

Zbog zabrinutosti država članica za nove ekološke probleme, kao i usklađenost ekološke zaštite i promena u ekonomskoj sferi donet je Prvi akcioni program o životnoj sredini formalno je prihvaćen od strane Saveta i predstavnika zemalja članica 1973.godine i predstavlja fundament ekološke politike današnje Evropske unije. Nazvan je Prvi akcioni program zaštite životne sredine. Njime su definisani ciljevi poboljšanja kvaliteta života, okoline i živih uslova neophodnih za stanovništvo 
zajednice. Devedesetih godina dvadesetog veka Evropska unija se zalagala za smanjenje emisija industrijalizovanih zemalja i podizanje ekolpške svesti. Ugovorom iz Mastrihta iz 1992. godine Evropska unija obezbeđuje jačanje uloge ekološke politike (Maastricht Treaty, 1992).

Takođe, treba istaći i šesti akcioni plan Evropske unije, koji je donet takođe 2001. godine i kojim su identifikovane četiri oblasti evropske ekološke politike: klimatske promene, zaštita prirode i biodiverziteta, zdravlje i kvalitet života, raspolaganje prirodnim resursima i pitanje otpada. Ovim akcionim planom identifikovano je sedam ključnih najugroženijih oblasti: zagađenje vazduha, iskorišćavanje resursa, zaštita zemljišta, reciklaža otpada, urbane sredine, održiva upotreba pesticida, ekološka zaštita mora (Sixth Environment Action Programme, 2001). Na osnovu šestog akcioninog plana doneta je Strategija održivog razvoja Evropske unije, kojom su definisani opšti ciljevi i konkretne akcije za sedam ključnih prioritetnih izazova za period od 2001. do 2010. godine. (European strategy for Sustainable Development" COM, 2001) i koja predstavlja sveobuhvatan okvir za sve politike i strategije Evropske unije.

Kada je reč o najvažnijim institucijama ekološke politike Evropske unije su: Evropska komisija, Genralni Direktorat za životnu sredinu, Evropski parlament, Komitet za životnu sredinu, zdravstvenu zaštitu i bezbednu ishranu, Savet ministara, i Evropska agencija za životnu sredinu.

Najveću i najvažniju ulogu u kreiranju ekološke politike EU ima Evropska komisija. U njene ingerencije spada predlaganje akata Savetu i Parlamentu, donošenje pojedinačnih odluka, praćenje implementacije ekološke politike, izrada strategija i planova, kao i pokretanje postupaka pred Evropskim sudom pravde protiv država koje ne poštuju odredve prava Evropske unije.

U okviru Evropske komisije za ekologiju je zadužen Generalni direktorat za životnu sredinu. Generalni direktorat za zaštitu životne sredine je specijalizovana služba Evropske komisije. Glavna uloga direktorata je da definiše ekološku politiku i osigura realizaciju ciljeva ekološke politike. Osnovna misija direktorata je zaštita očuvanje i unapređivanje životne sredine za sadašnje i buduće generacije i promovisanje održivog razvoja. Generalni direktorat postavljene ciljeve realizuje kroz višegodišnji strateški plan kojim se usklađuje ekološka politika sa političkim prioritetima Komisije, i utvrđuje strateški plan za period od 2016-2020. godine.

Evropska agencija za životnu sredinu je osnovana 1993. godine u Kopenhagenu je još jedna važna institucija, koja ima za cilj pružanje pouzdanih i nezavisnih informacija o životnoj sredini za one koji su uključeni u razvoj, usvajanje, implementaciju i evaluaciju ekološke politike, kao i za širu javnost. U bliskoj saradnji sa Evropskom mrežom za informisanje i posmatranje životne sredine i njenih tridesettri članica, Evropska agencija za životnu sredinu prikuplja podatke i daje procene o širokom spektru tema koje su u vezi sa zaštitom životne sredine.

\section{Izazovi ekološke politike Evropske unije}

Novi bezbednosni izazovi pogađaju životnu sredinu narušavajući biodiverzitet $i$ ugrožavajući život svih ljudi na planeti Zemlji. Osim klimatskih promena, značajni izazovi su ekonomske i bezbednosne okolnosti u Evropskoj uniji nastale nakon njenog proširenja, kao i pitanje evropskog identiteta. Još jedan aktuelan bezbednosni izazov tokom 2020 i 2021. godine je pandemija uzrokovana korona virusom koja je pogodila čitav svet i koja ne jenjava.

S obzirom na brojne izazove ekološke politike, neophodno je strateški definisati smernice i načine da se dostignu ekonomski, ekološki i socijalni ciljevi ekološke politike. Značajno je definisati i dugoročnu viziju, sveobuhvatne ciljeve, budžet za implementaciju ciljeva, efektivnu i efikasnu participaciju svih država članica Evropske unije (Dalal-Clyton, 2002).

Kao dva najznačajnija ekonomska izazova za ekološku politiku Evropsku uniju navode se: nepostojanje podjednake pažnje i investiranja u ostalim delovima sveta, pre svega Sjedinjene Američke Države, Kini, Indiji, čije rastuće industrije nisu obavezane da poštuju podjednako strogu ekološku legislativu, i problem konkurentsnosti evropskih preduzeća koja moraju da se nose sa povećanim troškovima (Lilić i dr., 2014).

Osim ekonomskog faktora kao važnog za kreiranje i implementiranje ekološke politike u EU, ključni izazovi su klimatske promene i evropski identitet. Klimatske promene predstavljaju jedan od najvećih ekoloških izazova sa kojima se čovečanstvo danas suočava. Klimatskim promenama se nazivaju značajne promene klimatskih uslova kao što su temperatura, padavine ili vetrovi koji traju deceniju ili duže, a mogu nastati kao rezultat: prirodnih procesa u okviru klimatskog sistema, promenama u intenzitetu Sunčevog zračenja ili pak ljudskih aktivnosti koje utiču na sastav atmosfere i površinu Zemlje (IPA: Climate Change Indicators in the United States. 2007).

Izveštaj Međunarodnog panela o klimatskim promenama ukazuje da možemo očekivati da do 2099. godine svet bude u proseku topliji za 1.8 do 
4 stepena celzijusa (IPCC: Climate Change, 2007). Očekuje se da će do 2050. godine velike pustinjske površine povećati svoje areale od 2 do $7 \%$ (Brown, 2008).

Evropska unija uložila je značajan napor u smanjenju štete do kojih klimatske promene mogu dovesti. Pravni osnov za aktivnosti EU na smanjivanju emisija gasova predstavlja Okvirna konvencija Ujedinjenih nacija o klimatskim promenama iz 1992. godine i prateći Kjoto protoko potpisan 1997. godine. U Protokolu je utvrđeno šest gasova koji izazivaju efekat staklene bašte i cilj je smanjenje emisije tih gasova za 8\% za period od 2010-2020. godine. Evropska unija je donela Evropski program o klimatskim promenama I za period od 20002004. godine, dok je danas na snazi Evropski program o klimatskim promenama II. Politika i regulativa EU u ovoj oblasti su razvijene i obuhvataju delovanje na polju ekološkog prava, energetske i transportne legislative.

Važan standard za očuvanje prirode i biološke raznovrsnosti je Natura 2000, koji predstavlja evropsku ekološku mrežu koja obuhvata zaštićena područja na teritorji država članica EU koja je uspostavljena na osnovu Direktive o staništima iz 1992. godine (NATURA 2000). Evropska ekološka mreža uključuje posebna zaštićena područja, suvozemna i pomorska. Direktiva o staništima i Direktiva o pticama predstavljaju do sada najambiciozniju inicijativu u okviru Evropske unije za zaštitu evropske prirodne baštine i ostvarenja cilja o zaustavljanju smanjenja biološke raznovrsnosti. Možemo zaključiti da Evropska unija ulaže značajne materijalne i ljudske resurse za finansiranje strategija, planova i ciljeva zaštite životne sredine.

Kada je reč o evropskom identitetu, prvi put se ovaj pojam javlja u psihologiji 1997. godine $u$ istraživanju Marka Cinirele. On je po prvi put merio izraženost evropskog identiteta većim brojem ajtema i svoj instrument bazirao na teoriji socijalnog identiteta, a isti istrument prilagodio za ispitivanje nacionalnog identiteta. Cinirela je poredio izraženost evropskog i nacionalnog identiteta kod stanovnika Velike Britanije i Italije, ali istovremeno i povezanost evropskog i nacionalnog identiteta kod obe grupe ispitanika. Njegovi rezultati su pokazali da je evropski identitet izraženiji kod italijanskih ispitanika, a i da je nacionalni identitet izražen kod obe grupe ispitanika (Cinnirela, 1997).

Bez obzira na to koji je identitet izraženiji u nekoj državi, izgradnja nacionalnog jedinstva jačanjem zajedničkog identiteta je fudament izgradnje demokratski ustrojene države nakon koje nastupa proces donošenja demokratskog ustava, integracija stanovništva unutar jedinstvenog pravnog poretka i stvaranje uslova za participaciju različitih društvenih skupina (Münkler, 1994). Bez saradnje država u rešavanju zajedničkih problema i u ostvarivanju zajedničkih ciljeva nema političkog ni ekonomskog progresa. Zato se države integrišu u regionalne organizacije, reformišu i evropeizuju kako bi zajedničkim snagama prosperirale.

Evropeizacija je moderan i aktuelan pojam, koji još uvek nema jedinstvenu definiciju, ali najcitiraniju i najšire prihvaćenu definiciju evropeizacije dao je Klaudio Radeli: „Evropeizacija je proces izgradnje, širenja i sprovođenja formalnih i neformalnih pravila, procedura, političkih paradigmi i zajedničkih normi i verovanja koje se prvo definišu i konsoliduju u okviru političkog delovanja u EU a zatim ugrađuju u logiku domaćih diskursa, identiteta, političkih struktura" (Radelli, 2003). U kontekstu evropeizacije nacionalne politike država kandidata se menjaju, reformišu i usklađuju sa evropskim. Cilj evropeizacije i evropskih integracija ne treba da bude samo punopravno članstvo države u EU, već reforma celokupnog sistema.

Politika proširenja uzima se kao značajan faktor analize povezanosti evropskog identiteta i ekološke politike. Politika proširenja Evropske unije je dovela do novih političkih, ekonomskih i kulturoloških okolnosti. Kada je reč o državama kandidatima za članstvo, evropeizacija se u svim oblastima i njihovim nacionalnim politikama odvija uslovljavanjem od strane Evropske unije, pri čemu se broj uslova povećava u svakom narednom krugu proširenja. U poslednjem velikom proširenju iz 2004. godine u kome je deset država pristupilo EU, uslovljenost je formalizovana kroz kopenhaške kriterijume (Conditions for membership, 1993).

Nakon tog velikog proširenja, Bugarska i Rumunija postale su članice EU 2007. godine, dok je Hrvatska 2013. godine. Od tada su vrata Evropske unije zatvorena za ostale kandidate i o proširenju se gotovo ne govori. U prilog tome je izjava Emanuela Makrona, predsednika Francuske, da Evropska unija neće primati nove članice, dok se ona reformiše i redefiniše.

Proširenjem Evropske unije povećava se broj članova u Evropskom savetu, Savetu ministra i Evropskom parlamentu što dodatno otežava proces donošenja i implementacije ekoloških regulativa. Treba istaći važnost projekta Otvorenog metoda koordinacije (OMC), koji je Evropska unija pokrenula sa ciljem proširivanja saradnje država članica u oblasti ekološke politike. Otvoreni metod koordinacije predstavlja instrument ekološke politike, koji nema pravnu obaveznost, već je preporu- 
ka EU državama članicama da samostalno odrede nivo saradnje i poštovanja principa u okviru ovog projekta (Szyszczak, 2006). Proširenjem EU takođe se povećava i broj bezbednosnih izazova, koji mogu ugroziti stabilnost EU i između ostalog i životnu sredinu.

\section{ZAKLJUČAK / CONCLUSION}

Ekološka politika predstavlja plansku i racionalnu upotrebu raspoloživih prirodnih resursa. Ekološka politika Evropske unije je razvijen i kompleksan segment delovanja, koji predstavlja odraz svesti o neophodnosti saradnje i zajedničke akcije svih država članica. Evropska unije ja svojim aktivnostima inicirala saradnju država članica, ali i onih koje nisu članice $u$ vezi sa zaštitom životne sredine i borbom protiv klimatskih promena.

Neki od izazovi u poboljšanju ekološke politike Evropske unije su klimatske promene i politika proširenja. Klimatske promene mogu dovesti do suša, požara i drugih prirodnih katastrofa koje uzrokuju velike ljudske i materijalne gubitke, dok politika proširenja može dovesti do novih bezbednosnih izazova, rizika i pretnji.

Osim normativno-pravnog i institucionalnog uređenja ekološke politike, važan preduslov za njenu implementaciju je postojanje ekološke svesti. Da bi države mogle sarađivati u oblasti ekološke politike, neophodno je da imaju svest o važnosti bavljenja ovom tematikom i o važnosti njihove pripadnosti evropskom identitetu.

Nakon velikog proširenja EU 2004. godine nastali su novi problemi zbog novih ekoloških izazova i nepoštovanja ekoloških standarda od strane novih država članica. Tako da pored značajnih aktivnosti EU u poboljšanju ekološke politike, važne su i aktivnosti država članica u kreiranju i implementiranju ekološke politike.

Bez obzira na to jesmo li ili nismo građani $i$ građanke Evropske unije, naša dužnost je da za buduće generacije očuvamo prirodno okruženje. To je moguće zajedničkim aktivnostima naučnika, političara i medija koji će udruženim snagama raditi na oblikovanju i podizanju ekološe svesti i unapređenju zaštite životne sredine.

\section{LITERATURA / REFERENCES}

[1] Alesina, A., Angeloni, I., Schuknecht, L., What does the European Union do? Public Choice, 2005

[2] Brown, O., Migration and Climate Change. IOM. Geneva. Switzerland. 2008

[3] Cinnirela, M., Towards a European identity? Interactions between the national and Europ- ean social identitites manifested by university students in Britain and Italy. British journal of social psychology, 36(1), (1997), 19-31.

[4] Čorkalo, D., Kamenov, Ž., Nacionalni identitet i međunacionalna tolerancija. Izveštaj $s$ VIII. Ljetne psihologijske škole. Zagreb: Odsjek za psihologiju, 1998.

[5] Dalal-Clayton, B., Bass, S., Recent progress and new thinking on strategies for sustainable development. Annual meeting of the International association for impact assessment, 2002

[6] Lilić, S., Drenovak-Ivanović, M. Ekološko pravo. Pravni fakultet Univerziteta u Beogradu, 2014.

[7] Meyer, J.W., Boli, J., Thomas, G.M., Ramirez, F.O. World society and the nation-state. American Journal of sociology, 103(1), (1997), 144-181

[8] Mihić, V., Da li smo mi Evropljani? Povezanost i korelati evropskog i nacionalnog identiteta. Psihologija 42(2), (2009), 203-220.

[9] Münkler, H., Nation as a Model of Political Order and the Growth of National Identity in Europe. International Sociology, 14(3), (1999), 283-299.

[10] Radaelli, C.M., The Europeanization of public policy, in: K. Featherstone and C.M. Radaelli (Eds), The Politics of Europeanization, Oxford: Oxford University Press, 2003, pp. 27-56

[11] Solomon, S. et al. (eds.), Climate Change 2007 - The Physical Science Basis, Contribution of Working Group I to the Fourth Assessment Report of the IPCC, Cambridge University Press, 2007

[12] Szyszczak, Erika. Experimental governance: the open method of coordination. European Law Journal, 12(4), (2006), 486-502

[13] Volf-Nidermajer, A., Evropa od A do Š - priručnik za evropsku integraciju, (Ekološka politika), Fondacija Konrad Adenauer, Beograd, 2004.

[14] https://www.eea.europa.eu/environmental-timeline/1970s

[15] http://www.europarl.europa.eu/factsheets/en/sh eet/71/environment-policy-general-principlesand-basic-framework

[16] https://europa.eu/europeanunion/sites/europaeu/files/docs/body/treaty_on _european_union_en.pdf

[17] https://eur-lex.europa.eu/legalcontent/EN/TXT/?uri=LEGISSUM\%3AI28027

[18] http://ec.europa.eu/dgs/environment/index_en. $\mathrm{htm}$ 
[19] https://europa.eu/european-union/abouteu/institutions-bodies/council-eu_en

[20] https://www.eea.europa.eu/about-us

[21] http://ec.europa.eu/environment/nature/natura2 000/index_en.htm

[22] https://www.ipcc.ch/publications_and_data/publ ications_ipcc_fourth_assessment_report_wg1_ report_the_physical_cience_basis.htmhttps://e c.europa.eu/clima/policies/eccp/second_de

[23] https://rs.n1info.com/svet/dw-prosirenje-eu-jemrtvo-sta-dolazi-umesto-toga/ 